\title{
AID FOR SISYPHUS: INCENTIVES AND CANADIAN CONTENT REGULATION IN BROADCASTING
}

\section{H.N. JANISCH*}

Measured against recent developments in Canadian content regulation in broadcasting, claims of an overall shift to incentive-policy instruments seem exaggerated. Nevertheless, even here there are signs of some move away from exclusive reliance on command-and-control type regulation in favour of investment incentives for indigenous programming.

In documenting this shift from "sticks to carrots" it is suggested that it would be inappropriate to think in terms of the traditional notions of administrative law fair procedures. although some minimal concept of "orderliness" in applying incentives might be appropriate.

\section{TABLE OF CONTENTS}

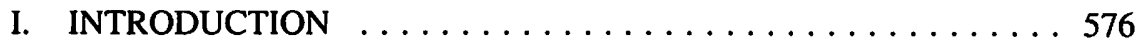

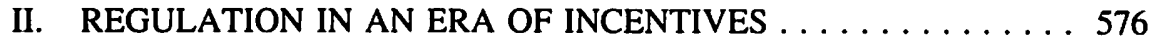

III. VARIATIONS ON COMMAND-AND-

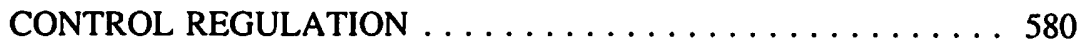

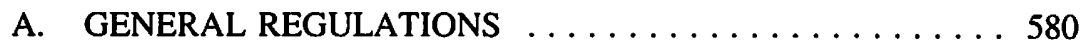

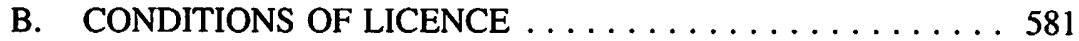

C. PROTECTION FROM

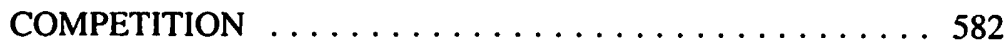

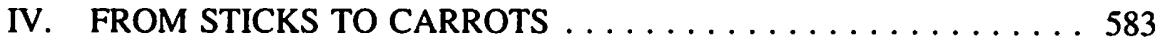

V. A TENTATIVE FLIRTATION WITH

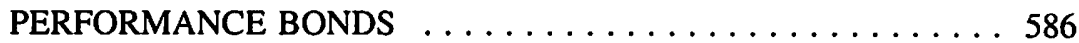

VI. TELEFILM CANADA AT WORK . . . . . . . . . . . . . 587

VII. CONCLUSIONARY CONSIDERATIONS: OF SYMBOLIC LAW AND SYMBOLIC

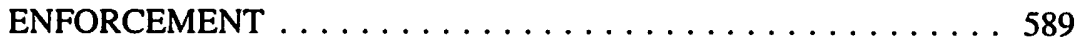

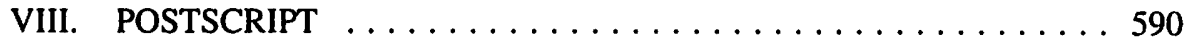

Weaknesses, abuses and failures are frequently found. But experimentation continues. No logical a priori theory can embrace the flux of actual government. New laws, new administrative forms appear. There is a persistent search for some workable means of adjusting the forms of governance to the uneasy needs of men. The story of the federal bureaucracy today is kept in a looseleaf ledger.

E. Pendleton Herring'

Faculty of Law, University of Toronto. A revised version of a discussion paper prepared for the Conference on "The Power of the Purse: Financial Incentives As Regulatory Instruments," University of Calgary, 12-13 October 1990.

I. E. Pendleton Herring, Public Administration and the Public Interest (New York: McGraw-Hill, 1936) at viii. 


\section{INTRODUCTION}

One of the most challenging tasks facing regulators in Canada today concerns Canadian content in broadcasting, especially with respect to English language drama on the now predominant private television networks. Currently, the public network, $\mathrm{CBC}$ has some $80 \%$ Canadian programming between 6 p.m. and midnight and private networks such as CTV and Global have achieved $50 \%$ or better in the same period. But these levels have been achieved chiefly with news, information and sports programming. Canadian drama, comedy and children's series still only make up a very small portion of peak viewing hours. For the 1989-90 fall weekly schedule between 6 p.m. and midnight, a total of 42 hours, CTV had 3 hours of Canadian drama programs scheduled; Global had 2 and the CBC 7. ${ }^{2}$

This dearth of English-language drama shows is not surprising as it costs a Canadian broadcaster about ten times as much to produce indigenous drama as it does to license U.S. drama. ${ }^{3}$ With economic incentives so strongly favouring importation rather than indigenous production, it is to be expected that the conventional command variety of regulation would not be successful. The purpose of this paper is to explore emerging alternative approaches and to serve as an initiatory document for further discussion of administrative law issues arising from the use of financial incentives compared with more direct forms of regulation.

\section{REGULATION IN AN ERA OF INCENTIVES}

Two years ago, at a symposium sponsored by the Law Reform Commission of Canada, three of my colleagues at the University of Toronto were moved to make the following bold and comprehensive statement:

One of the most striking features of government policy-making in the past fifteen years has been the extent to which incentive-oriented policy instruments have increasingly prevailed. Throughout the world there has been an increasing recognition of the importance of economic incentives in the policy calculus,

2. J.H. Cuff, "CanCon Could Use A Rewrite, But It Has Kept The Yanks At Bay" The [Toronto] Globe \& Mail (19 May 1990) C1.

3. C. Hoskins \& S. McFadyen, "Television in the New Broadcasting Environment: Public Policy Lessons from the Canadian Experience" (1989) 4 European Journal of Communication 173 at 178. Some further measure of the magnitude of the economic incentives involved may be seen in the most recent comprehensive review of Canadian broadcasting undertaken by the Task Force headed by Co-Chairmen Gerald Caplan and Florian Sauvageau.

[F]oreign programs are purchased at a small fraction of what it costs to produce them, usually less than 5 percent for a TV series and 1 or 2 percent for feature films. Hence for an expenditure of $\$ 133$ million, English private broadcasters bought the right to show programs that probably cost at least $\$ 3$ billion to produce, and might easily have cost $\$ 4$ billion or $\$ 5$ billion. It is not surprising that private broadcasters find this an attractive proposition, particularly when these shows come with the backing of extensive publicity and advertising that spills into the Canadian market.

Report of the Task Force on Broadcasting Policy (Ottawa: Minister of Supply and Services Canada, 1986) at 433. [hereinafter "Caplan-Sauvageau Report"] 
frequently reflected in a trend towards privatization, deregulation, and tax reform. This shift in instrument choice has been followed by governments of both the right and the left, and it has touched economic regimes which range along the spectrum from capitalist to socialist. ${ }^{+}$

They went on to urge that, far from diminishing the role for administrative lawyers, this shift in favour of incentive-oriented instruments posed a host of new challenges for those concerned with the administrative state. Administrative lawyers needed to understand why this recent shift in instrument choice had occurred, to interpret it accurately and to "...respond with imaginative forms of institutional design that permit more effective, smarter government on the one hand and even more robust expression of public values on the other."

In keeping with their thesis, a profound change in approach to the regulation of Canadian content in broadcasting was observed.

Traditionally, enforcement has been based upon making the renewal of broadcast licenses conditional on the fulfillment of Canadian content requirements. Yet in the case of a major television network such as CTV, outright withdrawal or suspension of a licence is such a blunt threat as to be almost entirely implausible. A regular ritual occurs as the CRTC cites the networks for inadequate compliance, the networks agree to make changes in their programming mix, and the licenses are routinely renewed. What is now proposed is a system whereby licence fees are adjusted to reward compliance and to punish noncompliance. That the changes are being fought hard by the networks is prima facie evidence that they may improve considerably enforcement of the rules. ${ }^{6}$

For one hunkered down in the trenches of communications law, reports from colleagues high above in their world-view observation balloons of a mass advance by incentive forces, seem overstated. There simply has not been any clear cut move to incentive regulation on the ground. As Sportin' Life observed of the dictates of conventional morality: "It ain't necessarily so." Or as Herring succinctly put it: "No logical a priori theory can embrace the flux of actual government." ${ }^{17}$ At the same time, something is afoot for there is today widespread disillusionment with the regulation of Canadian content. As John Meisel, himself a recent chairman of the CRTC, bluntly put it in 1989: "A gaping hole is evident between aspiration and fulfillment."

4. R. Howse, J.R.S. Prichard \& M.J. Trebilcock, "Smaller or Smarter Government?", (1990) 40 U.T.LJ. 498.

Ibid. at 499.

lbid at 525.

Supra note 1.

J. Meisel, "Fanning the Air: The Canadian State and Broadcasting." (Paper presented at the Royal Society of Canada's Symposium on The State and the Arts, 5 June 1989) at 2. For classic defences of the regulatory status quo by Meisel when Chairman of the CRTC, see, for example, "Babies and Bathwater, or, What Goes Down the Dercgulatory Drain" in Gandy, ed., Proceedings From the Tenth Annual Telecommunications Policy Research Conference (Norwood N.J.: Ablex Publishing, 1983) at 3-11; "An Audible Squeak: Broadcast Regulation in Canada" in Cultures in Collision, The Interaction of Canadian and U.S. Television Broadcast Policies (N.Y.: Praeger, 1983) at 129-37. 
Disillusionment is to be found across the political spectrum from Marxists and left wing Canadian nationalists such as Dallas Smythe ${ }^{9}$ and Hershell Hardin, ${ }^{10}$ to centre-ofthe-road nationalists such as Marc Raboy" and Robert Fulford ${ }^{12}$ and to historians such as Paul Rutherford, ${ }^{13}$ social critics such as Richard Collins, ${ }^{14}$ and classical economists such as Steven Globerman ${ }^{15}$ who, incidentally think that the whole endeavour is doomed from the start. However, those who believe that the fight is worth it are excruciatingly long in their descriptions of failed regulation, but in their prescriptions do not come to grips with fundamental causes. All too often the critics exhort: "More of the same, but make it work this time!"

In my view, even the latest in a long series of government reviews, the CaplanSauvageau report of $1986,{ }^{16}$ similarly failed to come to grips with fundamental causes.

\begin{abstract}
While the Report recognised that regulation had failed in the past, it did not address the institutional and structural context in which decisions had had to be made and this failure will perpetuate a regime of unenforceable regulation. Rather than shield private broadcasters from competition in return for what will inevitably remain unenforceable promises (no matter how draconian legal sanctions might be made to appear), it would have been better to focus on what could be improved in genuine public broadcasting. and leave commercial broadcasting to the dictates of the commercial market where it truly belongs. ${ }^{17}$
\end{abstract}

Two contemporary critics deserve special mention because they were actively involved for many years in the process they now criticize. John Meisel points out that while in virtually all the studies over the last sixty years, the diagnosis and recommendations have been strikingly similar, governments, regulators and broadcasters have consistently failed

9. D.W. Smythe, Dependency Road: Communications, Capitalism, Consciousness and Canada (Norwood, N.J.: Ablex Publishing, 1981).

10. H. Hardin, Closed Circuits, The Sellout of Canadian Television (Vancouver: Douglas \& McIntyre, 1985).

II. M. Raboy, Missed Opportunities: The Story of Canada's Broadcasting Policy (Kingston: McGillQueen's Univ. Press, 1990).

12. $\quad$ R. Fulford, "Promises, Promises," Saturday Night (July 1987) 5.

13. P. Rutherford, When Television Was Young: Primetime Canada 1952 - 1967 (Toronto: U. of T. Press, 1990). Rutherford concluded: "What a pity that the BBG [predecessor to the CRTC] didn't recognize the fallacy of Canadian content and urge the politicians to free private TV to do what it did best, supply American entertainment and sell time." Ibid. at 122. For a review of Rutherford which highlights its importance for Canadian regulators, see H.N. Janisch, "Book Review" (1990) I M.C.L.R. 108.

14. R. Collins, Culture, Communications and National Identity: The Case of Canadian Television (Toronto: U of T Press, 1990).

15. S. Globerman, Culture, Governments and Markets: Public Policy and the Culture Industry (Vancouver: The Fraser Institute, 1987).

16. Supra note 3. Bernard Ostry, Chairman and Chief Executive Officer of TV Ontario was so offended by Globerman's approach that he was moved to observe that "... since poetry has been defined as that which cannot be translated, culture may be said to be that which is inscrutable to economics, or at least to some economists." "Book Reviews" (1988) 31 Can. Pub. Admin. at 304 at 306. It should, however, be noted that Ostry is one who has joined the chorus of critics of conventional regulation of broadcasting.

17. H. Janisch, "Culture or Commerce?" (1987) 15 Intermedia 42 at 43. 
to implement many of the most important goals defined in those same studies. This realization brings him face to face with a profound conundrum.

In light of this, the central question confronting students of broadcasting in Canada - a question which, curiously, has to my mind never been adequately pursued is why numerous governments (in this context government includes the cabinet and the regulator) have failed effectively to apply the recommendations proposed in one way or another by all the inquiries they commissioned. Why the perpetual charade of inquiries, recommendations, failure, more inquiries, more recommendations, more failure and so on and on ${ }^{18}$

In his quest for an answer to his conundrum Meisel looks to the dominant value system of Canadians and concludes that we are deeply imbued with democratic values which preclude the blind acceptance of governmental edicts. He conjectures that we respect the state, probably more than do most Americans, but we also insist that there are areas in which we are entitled to considerable personal freedom. "If Americans believe that they have a God-given right to fool around with firearms, Canadians assume that their basic rights give them access to any television signals that modern technology makes available."19

Another feature of the dominant value system, which Meisel believes has had a profound effect on broadcasting, is the widespread support for the private, rather than the public, sector. He notes that the argument is sometimes made that Canadians have some form of innate preference for, and facility with, public, as distinct from private, enterprise. ${ }^{20}$ But, he suggests, there is "overwhelming evidence" that although we distrust state-run companies less than our southem neighbours, we generally prefer to rely on private, rather than public, initiative.

Views on how best to structure broadcasting enterprises are affected by these general predispositions, with the result that valuations of public broadcasters, notably the $\mathrm{CBC}$, but also the provincial systems, is ambivalent. The CBC enjoys the passionate support of some Canadians and the approbation of a majority, but there is also near universal preference for the private broadcasters who attract larger audiences than do the public ones. ${ }^{21}$

Meisel goes on to share a number of other highly provocative insights, some of which I will return to at the conclusion of this paper. In turning to the views of Bernard Ostry, it should be noted that after a long career at the Department of Communications and elsewhere in the federal bureaucracy, Ostry is now Chairman and Chief Executive Officer of TV Ontario. In a recent assessment of the impact of globalization in the entertainment industry, he called for an alliance among national public broadcasters as the only means of protecting cultural sovereignty.

"Fanning the Air," supra note 8 at 2 (emphasis in original).

Ibid. at 3. For an analysis of why the regulatory agency, the Canadian Radio-television and Telecommunications Commission, had to back down in 1970 from any serious restrictions on the massive importation of whole American television stations via cable see Hagelin \& Janisch, "The Border Broadcasting Dispute in Context" in Cultures in Collision, supra note 8 at 42-47.

Meisel cites as "the classic example of this genre of argument," H. Hardin, A Nation Unaware: The Canadian Economic Culture (Vancouver: J.J. Douglas, 1974).

"Fanning the Air," supra note 8 at 3-4. 
Years of experiment with regulation has proved totally ineffective in fostering national and regional culture.

The European community, alarmed at the power of the new international conglomerates, is now bent on introducing the same sort of regulation in an attempt to preserve cultural sovereignty. It won't work. ...Regulation can have little effect, especially since the newly deregulated commercial services desperately need cheap product from the United States if they are to be profitable."2

It is apparent that it is time to reassess and, if need be, redesign our regulatory structure. No doubt, an increased concern for incentives will be part of this process. As Charles Schultze noted, as far back as 1977, we ought to maximize the use of techniques that modify the structure of private incentives, rather than those that rely on the commandand-control approach of centralized bureaucracies. ${ }^{23}$ However, the regulators of Canadian content appear as Sisyphus, condemned to rolling a massive stone of regulatory aspiration up a steep hill of countervailing economic incentives, even in the face of continual failure.

\section{VARIATIONS ON COMMAND-AND-CONTROL REGULATION}

While it would be an exaggeration to suggest that there has been quite the level of federal experimentation perceived by Herring, ${ }^{24}$ it should not be concluded that Canadian content regulation has consisted only of conduct regulation endorsed by (ineffectual) threat of licence revocation or non-renewal. While this may have been an accurate description back in the 1970's, in the last decade there has been considerable experimentation, with a shift away from exclusive reliance on general regulations to more dollar specific conditions of licence along with tax policies and restricted competitive entry designed to create a viable basis of support for indigenous programming. And, as we shall see, there has even been some limited move towards incentive regulation. The result is a somewhat complicated push-pull/sanction-inducement regulatory environment in which the obvious major challenge is one of coordination in order to achieve effectiveness.

\section{A. GENERAL REGULATIONS}

Initially, the primary vehicle for promoting Canadian programming exhibition by Canadian broadcasters was by way of general content regulations which required private stations to show $60 \%$ Canadian programming on a full-day basis, and $50 \%$ in "prime time," a relaxed 6 p.m. to midnight, generously averaged over a full year.

As economists Hoskins and McFadyen conclude, Canadian private broadcasters have acted, their patriotic protestations at licence renewal time notwithstanding, in perfectly predictable fashion.

22.

23 .

B. Ostry, "The Risks in Going Global" New York Times (31 December 1989) H29.

C.L. Schultze, The Public Use of Private Interest (Washington, D.C.: The Brookings Institution, 1977 ) at 7. He notes (at 6) as well that, "...the collective-coercion component of intervention should be treated as a scarce resource."

Supra note 1. 
Conduct regulation, which attempts to cause private firms to act against the interests of their shareholders, invites token responses, and private stations have thwarted the intention of the prime-time quota by bunching Canadian programming in the early or late evening (thus leaving the peak period for the profitable U.S. programmes). Another ploy has been to concentrate Canadian programming in the summer off-season. A third has been to produce low-cost programming to minimize the possible loss from satisfying the Canadian content quota. ${ }^{25}$

In short, Canadian content has been seen as a cost of doing business, and like all other cost, it is to be kept to a minimum. Provided a licence was not placed in serious jeopardy (there was always plenty of opportunity, as Howse, Prichard and Trebilcock noted, for a "regular ritual" which allowed for the publicly contrite renewal of promise ${ }^{26}$ ), only the barest minimum would be achieved, outside, that is, reasonably popular Canadian programming in sports and information.

\section{B. CONDITIONS OF LICENCE}

In 1979, in renewing the CTV licence, the CRTC made a significant shift in instrument choice. CTV was required to produce, on an annual basis, an additional 26 hours of original Canadian programming. This was done, for the first time, by way of $s .7(1)$ of the Broadcasting $\mathrm{Act}^{27}$ which provided that licenses might be issued subject to "... conditions related to the circumstances of the licensee," and not under s. 6, which granted the Commission its general regulation-making authority. CTV objected that the condition of licence power was intended to deal only with matters of individualized detail. A greatly enhanced, far more specific, Canadian content requirement, the private network argued, should have been imposed by way of an amendment to the general regulations under $\mathrm{s}$. 6. Of course, in view of the legislative character of that section, the issue of CTV's contribution to Canadian content would have had to be dealt with in a less specific, and, from the regulator's point of view, less effective manner, had their argument prevailed. As it turned out, the Supreme Court of Canada upheld the CRTC, ${ }^{28}$ and specific conditions of licence have now become the primary means of extracting Canadian content commitments. ${ }^{29}$

\footnotetext{
25. Supra note 3 at 176.

26. Supra note 4 at 525 .

27. Broadcasting Act, R.S.C. 1985, c. B-9.

28. CRTC v. CTV Television Nenwork Limised, [1982] I S.C.R. 530.
}

29. See, for example, CTV Television Newwork Ldd., Decision CRTC 87-200 which provides:

The Commission requires, as a condition of licence, that CTV broadcast during Network Sales Time the following average of hours per week of regularlyscheduled Canadian dramas in each year of the licence term:

$1987 / 88 \quad 2.5$ hours per week

1988/89 3.0 hours per week

1989/90 3.0 hours per week

1990/91 4.0 hours per week

1991/91 4.5 hours per week

The Commission also requests, as a condition of licence, that in each ycar of the licence term, no more than one hour per week of the above-mentioned hours of regularly-scheduled Canadian drama be broadcast before 8:00 p.m. 
Most recently, an additional technique has been employed. The Commission has long insisted that where there is consolidation of ownership, concrete evidence of public benefit (in the form of further commitments to program production) will be required. This approach was carried one stage further in 1989 in the Maclean Hunter acquisition of Selkirk where the regulator insisted that the acquiring company invest the difference between the CRTC's valuation of Selkirk and the purchase price (some $\$ 21$ million) in a trust fund "... to strengthen and improve the Canadian broadcasting system." This, it should be noted, was over-and-above the $\$ 30$ million Maclean Hunter had already promised to support Canadian programming. ${ }^{30}$

\section{PROTECTION FROM COMPETITION}

Another strategy aimed at enticing broadcasters to exhibit Canadian shows, has been to protect them from competition in the hope that resulting profits will be spent on Canadian content. Measures adopted have included restrictive policies with respect to new stations which might compete for audiences with Canadian over-the-air broadcasts; Bill C-58 which discourages the placing of advertising aimed at Canadians on U.S. border stations by denying their tax deductibility as a business expense, and CRTC sanctioned "simultaneous substitution" whereby, when the same programme is shown simultaneously on a Canadian and a U.S. channel, the cable company is required to substitute the Canadian signal (and advertisements) for the U.S. signal. ${ }^{31}$ While such protection has helped to make private broadcasting on occasions very profitable, ${ }^{32}$ as Hoskins and McFadyen bluntly note "... there is no evidence that this [protection] has resulted in increased expenditures on Canadian programming. This is not surprising, as such measures do not affect the economic incentives that favour exhibition of U.S. programming. ${ }^{.33}$

The Commission expects their programs to reflect high production standards in order to be attractive to a wide Canadian audience. (Emphasis in original)

However, it should be noted that there has been significant dissention within the Commission over this move to reliance on much more specific conditions of licence. In 1983 when the CRTC announced its new approach, two Commissioners, Gagnon and Grace, dissented. "The goal of flexibility is not sufficient reason, in our view, to justify the substitution of unknown and shifting norms (applied by a changing cast of Commissioners from hearing to hearing) for clear, intelligent regulations." "CRTC Policy Statement on Canadian Content in Television" Notice 83-18, (31 January 1983) at 17.

See J. Partridge, "CRTC Approves Selkirk Takeover" The /Toronto] Globe \& Mail (29 September 1989) BI; D. Hatter \& J. Hubbard, "MH Gets OK on Selkirk" The Financial Post (29 September 1989) 1; J. Hubbard, "CRTC - Ordered Fund Irks Broadcasters" The Financial Post (2 October 1989) 3.

31. For details see Hagelin \& Janisch, "The Border Broadcasting Dispute in Context" in Cultures in Collision, The Interaction of Canadian and U.S. Television Broadcast Policies, supra note 8 at 40-99. See Caplan-Sauvageau Report, supra note 3 at 448. The Report was also somewhat ambivalent about the value of the substitution rule in developing Canadian programming as its immediate effect leads to counter-programming American peak viewing and this accentuates the importance of popular American prime time shows (459-61). It should also be noted that the tax ruling and the program substitution policy are predicated on an optimistic trickle down theory, and that it is far from clear that it is possible for a regulator to "squeeze" enhanced profits into uneconomic Canadian content. There is likely to be many "slips 'tween cup and lip" in this type of regulatory regime. 


\section{FROM STICKS TO CARROTS}

It was apparent by the early 1980's that the "stick" of direct regulation was by and large incapable of inducing conduct contrary to the economic self-interest of private broadcasters. ${ }^{34}$ As noted in the Law Reform Commission of Canada's Working Paper 51, Policy Implementation, Compliance and Administrative Law, "Licensing, on its face, appears to carry grave consequences for non-compliance: however, licensing actually provides a framework for informal bargaining about content. In fact, CRTC practice has entrenched tenure in licences. Loss of licence for failure to meet content requirements is a remote possibility at best, and licensing relations are substantially different from what one might expect on reading the legislation. ${ }^{\text {"35 }}$

At much the same time as there was a growing perception that licence revocation (or even short-term renewal) was, for practical purposes, an unusable blunt instrument, it was also recognized by policy-makers that new transmission technologies, such as satellite and multi-channel cable, meant that, with ever increasing choice, Canadians would simply not watch unattractive indigenous programming. As explained in the government's 1983 policy paper, Towards a New National Broadcasting Policy:

In the new broadcasting environment, regulation is not sufficient to preserve an identifiable Canadian broadcasting system. In particular, it is vital that the private Canadian program industry have additional funds at its disposal in order to compete with the flood of foreign programming now available because of the new technologies. ${ }^{36}$

Under the Memorandum of Understanding ${ }^{37}$ of February 21, 1983, the Canadian Broadcast Program Development Fund was established to be administered by Telefilm Canada, a government agency initially established by statute to support the production of feature films. ${ }^{38}$ The Memorandum of Understanding provided that assistance was to be made available only to certain categories of programming, especially drama, variety and children's fare where local production had been particularly weak.

Telefilm Canada was given discretion as to whether its involvement in the production of a particular programme was to be in the form of a loan, loan guarantee, equity or some mix of these. Producers are required to raise at least $\$ 2$ for every $\$ 1$ investment from the Broadcast Fund. The Memorandum of Understanding further provided that the Fund was

This was particularly true for English private television. However, it should be noted that Canadian content regulation has been quite successful with respect to private radio. See Caplan-Sauvageau Report, supra note 3 at 389-413. This is most probably accounted for by the much lower cost of radio programming compared to television and because American radio has not been imported holus bolus into Canada by the cable industry as has television.

35. Law Reform Commission of Canada, Policy Implementation, Compliance and Administrative Law. (Working Paper 51) (Ottawa: Department of Supply and Services, 1986) at 24.

36. Canada, Department of Communications, Towards a New National Broadcasting Policy (Ottawa: Minister Supply \& Services, 1983) at 7. (emphasis Added).

37. Minister of Communications, Memorandum of Understanding Concerning the Establishment of the Canadian Broadcast Development Fund (Ottawa, 1983). 
available only to private Canadian production companies and independent producers. In addition, producers were required to obtain a letter of intent from a Canadian broadcaster to exhibit the programme within two years of its completion.

The Memorandum of Understanding was amended in 1985 and fund eligibility widened to include documentaries. A letter of intent from a provincial educational broadcaster now qualified programmes for funding. The maximum level of Telefilm investment was increased to 49 per cent. ${ }^{39}$ In order to qualify for this increased limit, a programme had to earn the maximum of 10 points, rather than the standard 6 points, on the CRTC's tenpoint scale for determining Canadian content. This point system is based on the nationality of production inputs -2 points for the director being Canadian, 2 points for the writer being Canadian, one point each if the leading performer, head of art department, director of photography, music composer and editor are Canadian. ${ }^{40}$

The Broadcast Fund subsidizes investment in Canadian drama, variety, children's and documentary programming because experience has shown that private venture capital is not available to provide the necessary funding. As Hoskins and McFadyen explain:

Ex ante the Broadcast Fund provides downside risk protection as it reduces the size of loss for other investors associated with any level of revenue generation below cost, while ex post it provides a subsidy for projects which fail to recoup all investment costs. If Broadcast Fund investments are made partially or wholly subordinate to that of other investors, the latter may recoup all their investment while Telefilm bears the loss. It thus makes Canadian programming more economically attractive to Canadian producers, broadcasters, and other investors."

As with any subsidy system, it may be justified if the benefits from the positive externalities of having citizens exposed to additional Canadian programming which may increase a sense of Canadian identity and awareness of Canadian themes and values amongst viewers, is judged to outweigh the dollar cost of the subsidy necessary to induce the extra programming.

The Broadcast Fund has been widely regarded as successful and has escaped the latest round of federal government spending cutbacks. ${ }^{42}$ CTV's expenditure on Canadian content is reflective of a surge of spending on English-language projects, largely made possible by support from the Fund. In 1984-85 CTV contributed less than one per cent of programming expenditures for English-language broadcasting - in 1987-88 this amounted to twenty-seven per cent. ${ }^{43}$

A particularly useful overview of the evolving role of Telefilm Canada in support of television programming is to be found in the Caplan-Sauvageau Report, supra note 3 at $361-75$. See, as well, Telefilm Canada, Annual Report 1989-1990, at 17-29.

42. J. Nunes, "CBC, Telefilm Sigh With Relief After Budget Brought Down" The /Toronto/ Globe and Mail (22 February 1990) C7.

43. Hoskins \& McFadyen, supra note 3 at 182. 
In 1989 the then chairman of the CRTC, Keith Spicer, while calling for better quality shows on private television singled out CTV for having made "substantial progress" on the Canadian programming front. The historical series "Divided Loyalties" was praised as "a trial blazing effort of enormous scope," as was "The French Revolution," a $\$ 50$ million historical drama which provided eight hours of Canadian content for CTV thanks to funding from Telefilm. ${ }^{44}$

However, there has been some criticism that highly successful programs such as "Night Heat" have simply been "American clones." Because Telefilm Canada has, in recent years, placed great emphasis on recoupment of investment rather than uniquely Canadian cultural distinctiveness, this concern remains. ${ }^{45}$ As Mavor Moore, the first program director of CBC English television, has cautioned, "What governs the situation here is the American style. As long as we are trying to put Canadian content into American packaging, it's self-defeating. ${ }^{46}$

There have also been a number of management problems with accusations of political interference, favouritism, inadequate financial controls and the highly-publicized resignation of Telefilm's executive director. ${ }^{47}$ In the past, all this has done little good for the agency's ostensible independence and even-handedness, although it would now appear that immediate management and financial problems have been largely resolved.

By far and away the most disturbing aspect of the Broadcast Fund is that it has not acted as a genuine incentive. Participation is based on total project budget and this provides no incentive for broadcasters to increase their licence fees, i.e. the proportion of production costs they cover. As the Caplan-Sauvageau Report warned, "The fact that independent producers rarely recover more than twenty percent of their costs from sales in their home market remains the key problem that must be addressed." ${ }^{48}$ In brief, far from priming the pump, the Broadcast Fund is in danger of becoming a system of

J. Hubbard, "Broadcasters Told Spending Must Rise" The Financial Post (25 May 1990) I: "CRTC Chairman Plans to Rethink Canadian Content Rules for Television" The [Toronto] Globe and Mail (25 May 1990) B5.

The Caplan-Sauvageau Report, supra note 3 at 371-375, was adamant that Telefilm supported programming should be "genuinely" Canadian.

46. As quoted in "Cancon Could Use a Rewrite ..." supra note 2. (Emphasis in original).

47. See, for example, M. Fraser, "Telefilm Invests \$86 Million, Returns \$17 Million Unspent" The [Toronto/ Globe and Mail (1 September, 1987) D7; B. Amiel, "High Drama In The World Of Film" Maclean's (14 September 1987) 7; Canadian Press, "Pearson Quits Job At Telefilm Canada" The [Toronto] Globe and Mail (17 October 1987) C13; J. Partridge, "Ottawa Seeks to Minimize Rumors of Telefilm Crisis" The [Toronto] Globe and Mail (2l October 1987) B8; R. Lerch, "Money Woes Thicken Telefilm Plot" The Financial Post (2 November 1987) 8; H. Winsor, "Macdonald Aide Denies Director of Telefilm Quit Because of Interference" The /Torontol Globe and Mail (19 February, 1988) A5; M. Fraser, "The Multi-Million-Dollar Drama of Telefilm is Not Yet Over" The (Toronto] Globe and Mail (4 June 1988) at Cl; Canadian Press, "Telefilm's Finances For Film Dry Up Again" The /Torontol Globe and Mail (21 September, 1988) C7; S. Godfrey, "Telefilm Executives Counter Criticisms" The [Toronto] Globe and Mail (2 September 1988) C7.

48.

Supra note 3 at 371 . 
handouts with broadcasters joining David Lewis' parade of "corporate welfare bums." ${ }^{49}$ There is a danger that increases in participation by the Fund will simply be used by broadcasters as an opportunity to reduce their own contribution. An incentive formula would appear called for, possibly involving a two-tier level of support. The first tier might provide a fixed dollar investment, which would likely vary with programme type. The second tier would involve a dollar-for-dollar matching of broadcast licence fees. ${ }^{50}$

\section{A TENTATIVE FLIRTATION WITH PERFORMANCE BONDS}

The new Broadcasting Act ${ }^{51}$ will allow the CRTC to assess a fee against each private broadcaster at the start of each year. If a licensee met its Canadian content requirements, the fee would be reimbursed; if it fell short of its target, it would forfeit part of the "performance bond" to the government. 52

The whole scheme is entirely dependent on support from the CRTC, and the former CRTC Chairman André Bureau was highly dismissive of the whole idea. While Minister Macdonald urged an unreceptive audience at the Annual Convention of the Canadian Association of Broadcasters in 1987 to consider the merits of her proposal ("It gives you more choice in your programming decisions than would a highly specific regulatory requirement"), the Chairman dismissed the notion as being of only speculative advantage ("We cannot afford to wait years to see if a new mechanism could work when we already have one - Telefilm . that does work which we should encourage."). ${ }^{53}$ Unless the CRTC reverses its opposition, it would not appear that this particular experiment will fly. The Commission appears to have reached its limit for experimentation, Herring optimism notwithstanding. ${ }^{54}$ It should be noted as well, that as the new Broadcasting Act contains a number of additional powers for direct regulation, including the power of the CRTC to ask the courts to enforce mandatory orders, ${ }^{55}$ it cannot be said that "incentive-oriented policy instruments have increasingly prevailed"56 in Canadian content regulation outside, that is, of important developments with respect to Telefilm Canada and the Broadcast Fund, which is, as we have seen, in its present form not really a true incentive scheme.

It is encouraging to note that for 1989-90 Telefilm Canada reported that private investments rose steeply reaching $\$ 67.1$ million or $30 \%$ of television programme budgets as compared with $\$ 34.5$ in 1988-89. Telefilm Canada, Annual Report 1989-1990, supra note 39 at 12. This has been suggested by Hoskins \& McFadyen, supra note 3 at 186-87. Broadcasting Act, R.S.C. 1991 c. 11.

This would be possible under s. 11(2) of the Broadcasting Act, ibid. which allows for licence fees to be calculated according to the performance of licensees in relation to the broadcasting of Canadian programs.

3. B. Anderson. "Pay Fee To Ensure Canadian Content Flora Macdonald Tells Broadcasters" The [Toronto] Globe and Mail (17 November, 1987) D9; J. Partridge, "CRTC Chief Takes Pot Shot At Licensing Fee Suggestion Recently Floated By Minister" ibid. at B10.

Supra note 1.

Broadcasting Act, supra note 51, s. 13.

As suggested by Howse, Prichard and Trebilcock, supra note 4. 


\section{TELEFILM CANADA AT WORK}

Rather than seek to force agencies such as Telefilm Canada into a pre-existing administrative law Procrustean bed, it might be better to look at how the agency itself behaves, and then to seek ways to reinforce improvements in its administrative processes. ${ }^{57}$ This approach would seem to be particularly appropriate in Telefilm Canada's case because, as we have seen, it has recently weathered a rough period of resignation and accusations of favouritism but now seems to be operating on a more even keel.

The first point to note is that the agency has gone quite some way to inform those seeking financial support of the criteria it applies in its decision-making. Not only is the Annual Report a useful starting point for an understanding of how it sets about its business, but it is supplemented by an additional publication, Action Plan for the Administration of Telefilm Canada Funds, 1990-1991. As well, there are a series of policy pamphlets covering the full range of the agency's activities. The Canadian Broadcast Program Development Fund, Policies 1990-1991 sets out in commendable detail the basic principles governing support for television programming. It rightly emphasizes that as there are routinely more applications than available funding, decisions have to be made on the basis of a wide-ranging comparative analysis. The decisionmaking process is said to include consideration of the following:

[Q]uality of script writing, originality (visual treatment, filmic and TV language, narrative construction, dialogues, etc.), Canadian content, track record of the director, creative package (producer, director, scriptwriter, artistic director, director of photography, etc.). production team (production house, producer, executive producer, production director), marketing team (distributor, exporter), commercial potential, cultural impact, financial structure, realistic budget, quality, recoupment schedule and the project's general contribution to the advancement of national production. ${ }^{58}$

This is, of course, quite far removed from adjudication against a fixed standard which has largely been the progenitor of procedures developed in administrative law.

One way of looking at Telefilm Canada is as a sophisticated commercial lending agency which acts by way of complex "deal letters" much as do private investors. The crucial difference, of course, is that it is an investor who deliberately makes "dumb" investments, i.e. ones which make little short-term financial sense, but are culturally significant. This public policy investment objective necessitates the greatest flexibility and suggests great caution in the imposition of procedures other than those developed by the

57. The sub-title is a respectful doff of the cap to the contribution of John Willis to a pragmatic agency oriented-approach to administrative law. See his pioneering Canadian Boards at Work (Toronto: Macmillan, 1941).

As well, this was the approach initially adopted to administrative law reform at the Law Reform Commission of Canada. See the Commission's prolific Administrative Law Series of agency studies in the late 1970's.

Telefilms Canada, The Canadian Broadcast Program Development Fund, Policies 1990-1991 at 24. 
agency itself. It would also suggest that any rights-based review of substantive outcomes would be inappropriate.

By way of contrast, a funding agency could be treated as a government agency like any other which would be subject to the general principles of administrative law. This seems to be the approach adopted by Kernaghan Webb. ${ }^{59}$ It carries with it a determination to spread the "fairness revolution" into all aspects of government financial incentives.

I would urge that thought be given to developing a middle ground between these two positions. It does not seem to me appropriate to transpose what are essentially adversary procedures into a comparative evaluation process. I would plead not for fairness or natural justice, but for "orderliness." This notion would take emphasis away from the individual application and be more concerned with the integrity of the entire system of decisionmaking. ${ }^{60}$ In this manner Telefilm Canada may serve as a positive case study of what can be done with respect to public decisional criteria, thereby enhancing consistency and predictability. Improvement will have to come not by occasional forays in the courts, but through a learning experience based on the study of the practices of better agencies. It would mean that law reform work should take more of the form of continuous continuing education than intermittent reports. ${ }^{61}$

This incremental approach would reflect the realities of the situation. As I have suggested elsewhere, "... there is a natural reticence on the part of 'repeat players' to resort to direct challenges which may interfere with a continuing relationship with the regulator." ${ }^{62}$ It would be pointless to wait for judicially imposed procedures because there are no sufficient incentives for the disappointed to carry their grievances to the courts. One does not bite the hand which usually feeds one. There appears to be only one exception and that is with respect to the apparent willingness of Telefilm Canada to put a producer or distributor in default. In order to deal with possible financial shenanigans, the default policy provides:

Law Reform Commission of Canada, The Legal Framework for Financial Incentives as Regulatory Instruments by K. Webb (Ottawa: Law Reform Commission of Canada, 1990). to loose sight of the broader picture. "Administrative lawyers," it has been insightfully observed, "are formally trained in how to prevent government from acting arbitrarily against private interests, rather than in how to make government action more effective in the public interest". Roger Woll, American Bureaucracy (N.Y.: W.W. Norton, 1977) at 77. And as Bernard Schwartz has observed, "The lawyer tends to concern himself, as it were, with only the outer periphery of the administration, i.e. with those cases that flower into a formal controversy. ...this picture of the administrative process is of necessity a limited and even a distorted one, for he normally shuts his eyes to what constitutes the great proportion of the normal work of administration." Schwartz, Administrative Law (Boston: Little Brown, 1976) at 28. the Law" (1989) 2 C.J.A.L.P. 263 at 281-85. 
Telefilm Canada will evaluate an unusual situation relating to projects for which a company has obtained, directly or through an affiliate company, financing from the Corporation, and will apply the appropriate sanctions where necessary.

In addition to freezing all activities with companies in default, as per its contractual agreements, Telefilm Canada will systematically charge monthly interest on all overdue monies. ${ }^{63}$

Vigorously applied, this default policy can have a substantial financial impact on persons who might feel that they have nothing further to lose by avoiding a legal challenge. Thus they might well be prepared to go to court, and given the essentially penal nature of the default policy, a court may well be sympathetic. But outside of this unusual situation, it would seem unlikely that procedures to govern financial incentives will be developed by the judiciary.

\section{CONCLUSIONARY CONSIDERATIONS: OF SYMBOLIC LAW AND SYMBOLIC ENFORCEMENT}

Fulford and Meisel have both broken through the usual level of conventional analysis, and have raised some rather disturbing questions that should be addressed before closing.

Fulford concludes that what may account for the dearth of appealing Canadian feature films and television drama is lack of self-confidence. Money does not appear to be the culprit.

[An] innocent observer, coming fresh to broadcasting in Canada would be impressed not by how little money our system contains, but by how much. A great fortune flows through Canadian broadcasting every year. Aside from about \$850-million Parliament puts in the hands of the CBC, tens of millions are provided by Telefilm Canada, and advertisers pay public and private broadcasters about \$1-billion. ${ }^{64}$

What is missing then, is a sense of purpose. Fulford recalled a point made by Norman Jewison in a 1985 interview. "He acknowledged that Canadian filmmakers have special problems, including proximity to the United States, but 'On the other hand, not enough of our filmmakers have been committed to making a film from their gut, from their heart. They've always been saying What project can I get which will fly? ... What will make it easy to raise money?"' 65 If this is true, all that Telefilm Canada does is satisfy a quest for security, not creativity.

For John Meisel, at heart it may be all a matter of symbolic politics:

Successive (and, alas, continuing) failures to implement key elements of the various broadcasting policies can, therefore, be ascribed to the inability of the government and of the CRTC to muster either the will or the clout (or both) needed to impose them. The reason does not lie in some inherent weakness of character on the part of the government and the CRTC but rather in the fact that there was not, and is 
not, enough politically effective support in the country behind the nationalist and pro-public broadcasting assumptions of the legislation and the regulations needed to apply them. Pogo's celebrated dictum applies:

"We have identified the enemy and it is us."

Yet the question remains, if we are truly democrats, why should this outcome be a matter of regret and lamentation? And there is surely no little poignancy in it being an American cultural icon that is called on to urge Canadians to take the measure of themselves!

\section{POSTSCRIPT}

I must confess that I rather fancy the picture of Canadian content regulators toiling like Sisyphus in an endless task of rolling a stone up the steep hill of contradictory economic incentive. However, Camus, for one, sees things differently. "The struggle itself toward the heights is enough to fill a man's heart. One must imagine Sisyphus happy." ${ }^{\text {"67 }}$ This seems to me not existential, but merely masochistic. 